\title{
Amino acid requirements of pigs. 2. Requirement for apparent digestible threonine of young pigs
}

\author{
J. B. SCHUTTE', M. W. BOSCH${ }^{1}$, N. P. LENIS 2 , J. DE JONG ${ }^{1}$ \& J. TH. M. \\ VAN DIEPEN2 \\ 1 TNO Institute of Animal Nutrition and Physiology, P.O. Box 15, NL 6700 AA Wagenin- \\ gen, Netherlands \\ 2 Research Institute for Livestock Feeding and Nutrition, P.O. Box 160, NL 8200 AD \\ Lelystad, Netherlands
}

Received 5 March 1990; accepted 9 May 1990

\begin{abstract}
Six trials involving a total of 460 young pigs were performed to study the threonine requirement during the live weight range of approximately 20 to $40 \mathrm{~kg}$. To a negative control diet, containing $160 \mathrm{~g}$ crude protein and $5.6 \mathrm{~g} \mathrm{~kg}^{-1}$ threonine, four additions of $\mathrm{L}$-threonine $(0.0$, $0.6,1.2$ and $1.8 \mathrm{~g} \mathrm{~kg}^{-1}$ ) were tested. Results were compared with those of a positive control diet with $185 \mathrm{~g} \mathrm{~kg}^{-1}$ crude protein and $6.8 \mathrm{~g} \mathrm{~kg}^{-1}$ threonine. The negative control diet was supplemented with lysine, methionine, tryptophan, isoleucine, histidine and valine in order to be sure that no other amino acids than threonine were limiting. The positive control diet was supplemented with lysine and methionine. The experimental diets were fed ab libitum as pellets. In two separate trials, the apparent faecal and ileal digestibility of the amino acids of the two control diets was determined. The requirement for total threonine was found to be $7.1 \mathrm{~g} \mathrm{~kg}^{-1}$ for maximum weight gain, and $7.4 \mathrm{~g} \mathrm{~kg}^{-1}$ for maximum efficiency of feed utilization, in a diet containing $2290 \mathrm{kcal} \mathrm{kg}^{-1}$ net energy. These figures correspond with 6.2 and $6.5 \mathrm{~g} \mathrm{~kg}^{-1}$ faecal digestible and 5.7 and $6.0 \mathrm{~g} \mathrm{~kg}^{-1}$ ileal digestible threonine, respectively. Pig performance on the negative control diet supplemented with the first limiting amino acids, was almost similar to that on the positive control diet.
\end{abstract}

Keywords: pigs, threonine, requirement, digestibility

\section{Introduction}

In the Netherlands, nitrogen $(\mathrm{N})$ pollution of the environment is becoming a major problem. A substantial part of this $\mathrm{N}$ is excreted by pigs and poultry, in areas with dense populations of these animals (Lenis, 1989). Nitrogen excretion can be reduced by increasing the digestibility of the feed protein and/or increasing the utilization of the absorbed nitrogen. About $75 \%$ of the nitrogen loss is excreted via the urine.

Not only the crude protein (CP) content of the diet, but particularly the contents of the individual digestible essential amino acids determine the value of the feed pro- 
tein. Normally, Dutch pig diets are composed on the basis of the requirements for faecal digestible lysine and methionine + cystine. This results in an oversupply of other amino acids. When the amino acid profile of the feed protein is close to the amino acid profile needed for maintenance and production, utilization of the nitrogen can be high. When the CP content of the diet is lowered, after lysine and methionine, in present-day feed formulations threonine and tryptophan are becoming limiting.

The contents of amino acids in diets for pigs, recommended by ARC (1981), are related to the lysine content. For threonine, the ARC (1981) recommends a dietary level of $6.5 \mathrm{~g} \mathrm{~kg}^{-1}$ for pigs in the weight range of $15-50 \mathrm{~kg}$, which corresponds with $60 \%$ of the lysine content. Lewis et al. (1986) estimated the threonine requirement for pigs in the weight range of $5-15 \mathrm{~kg}$ at $7.0 \mathrm{~g} \mathrm{~kg}^{-1}$. The dietary lysine level was $12.8 \mathrm{~g} \mathrm{~kg}^{-1}$, thus threonine requirement was $55 \%$ of that of lysine. Rosell \& Zimmerman (1985) similarly found a threonine requirement of $7.0 \mathrm{~g} \mathrm{~kg}^{-1}$ for pigs weighing $5-15 \mathrm{~kg}$. This corresponded with $60 \%$ of the lysine requirement. GomezRojas et al. (1985) found, for pigs in the weight range of $16-33 \mathrm{~kg}$, a threonine requirement of 5.5-5.7 $\mathrm{g} \mathrm{kg}^{-1}$ (lysine $8.6 \mathrm{~g} \mathrm{~kg}^{-1}$ ). Wang \& Fuller (1989) advised, in their revised ideal amino acid pattern for growing pigs, a threonine level of $72 \%$ of the lysine level.

The requirement for amino acids is strictly a requirement for ileal digestible amino acids (Herrmann et al., 1988). Differences in ileal digestibility can possibly explain the wide rang of requirement figures for total threonine. The studies reported in this paper were carried out to determine the requirement for ileal digestible threonine of young pigs in the live weight range of approximately 20 to $40 \mathrm{~kg}$.

\section{Materials and methods}

The studies involved two digestibility trials, for determination of the contens of apparent faecal and ileal digestible amino acids in the basal diets used, and six growth trials. The trials were performed at two institutes: the TNO-Institute of Animal Nutrition and Physiology (ILOB), Wageningen, and at the Research Institute for Livestock Feeding and Nutrition (IVVO), Lelystad.

\section{Diets}

The composition of the two basal diets (coded as A and B) used, is presented in Table 1. Basal diet $A$ was used as a positive control diet and analysed to contain 185 $\mathrm{g} \mathrm{kg}^{-1}$ crude protein (CP), and $6.8 \mathrm{~g} \mathrm{~kg}^{-1}$ total threonine. Basal diet B was used as a negative control diet and analysed to contain $160 \mathrm{~g} \mathrm{~kg}^{-1} \mathrm{CP}$ and $5.6 \mathrm{~g} \mathrm{kg-1}$ threonine. Four additions of L-threonine $\left(0.0,0.6,1.2\right.$ and $\left.1.8 \mathrm{~g} \mathrm{~kg}^{-1}\right)$ to basal diet $\mathrm{B}$ were tested, resulting in dietary theonine levels of $5.6,6.2,6.8$ and $7.4 \mathrm{~g}$ $\mathrm{kg}^{-1}$, respectively. Both diets were supplemented with the same antibiotic (40 ppm Tylosine). Both diets were calculated to contain approximately 2290 kcal net energy $\mathrm{kg}^{-1}$. Basal diet $\mathrm{B}$ was supplemented with lysine, methionine, tryptophan, isoleucine, valine and histidine in order to be sure that no other amino acids than threo- 
Table 1. Composition of the two basal diets $\left(\mathrm{g} \mathrm{kg}^{-1}\right)$.

Basal A

Basal B

Ingredients

Tapioca

Barley

Corn

Soya flour

Corn gluten meal

Alfalfa

Skim milk powder

Cane molasses

Soya oil

Limestone

Dicalciumphosphate

Salt

Vitamin/mineral premix 1

L-lysine HCL

DL-methionine

L-isoleucine

L-tryptophan

L-histidine

L-valine

Analysed contents

Crude protein $(\mathrm{CP})$

Dry matter (DM)

Ash

Crude fat

Crude fibre

Nitrogen free extract (NFE) 2

Net energy (calculated $\mathrm{MJ} \mathrm{kg}^{-1}$ )

$\mathrm{Ca}$

$\mathbf{P}$

1 The vitamin/mineral premix supplied per $1 \mathrm{~kg}$ feed: $9000 \mathrm{IU}$ vitamin A, $1800 \mathrm{IU}$ vitamin $\mathrm{D}_{3}, 40 \mathrm{mg}$ DL- $\alpha$-tocopheryl acetate, $5 \mathrm{mg}$ riboflavin, $30 \mathrm{mg}$ niacin, $12 \mathrm{mg}$ d-pantothenic acid, $250 \mathrm{mg}$ cholinechloride, $40 \mu \mathrm{g}$ cobalamin, $3 \mathrm{mg}$ menadione, $50 \mathrm{mg}$ ascorbic acid, $0.3 \mathrm{mg}$ folic acid, $160 \mathrm{mg} \mathrm{Cu}, 80 \mathrm{mg}$ Fe, $73 \mathrm{mg} \mathrm{Zn,} 44 \mathrm{mg} \mathrm{Mn}, 0.5 \mathrm{mg} \mathrm{Co}, 0.06 \mathrm{mg} \mathrm{Se}, 0.4 \mathrm{mg} \mathrm{I}$ and $40 \mathrm{mg}$ Tylosin.

${ }^{2} \mathrm{NFE}=\mathrm{DM}-$ ash $-\mathrm{CP}$ - crude fat - crude fibre.

nine were limiting in this diet. Basal diet A was only supplemented with lysine and methionine.

Before inclusion in the diets, all feed ingredients, except for tapioca, were analysed for $\mathrm{CP}, \mathrm{Ca}, \mathrm{P}$ and amino acids. Based on these figures, the basal diets were composed. The experimental diets were mixed as one batch for all experiments. The two basal diets were analysed for the contents of $\mathrm{CP}, \mathrm{Ca}, \mathrm{P}$ and amino acids (Table 2). 
Table 2. Analysed contents of amino acids in the two basal diets (in $\mathrm{g} \mathrm{kg}-1^{-1}$.

\begin{tabular}{lcc}
\hline Amino acids & Basal A & Basal B \\
Isoleucine & 7.8 & 7.2 \\
Leucine & 16.4 & 14.2 \\
Lysine & 10.2 & 10.4 \\
Methionine & 3.4 & 3.8 \\
Cystine & 3.0 & 2.7 \\
Methionine + cystine & 6.4 & 6.5 \\
Phenylalanine & 9.0 & 7.4 \\
Tyrosine & 6.8 & 6.0 \\
Threonine & 6.8 & 5.6 \\
Tryptophan & 2.2 & 2.2 \\
Valine & 9.3 & 8.2 \\
Arginine & 10.2 & 8.0 \\
Histidine & 4.2 & 4.0 \\
& & \\
Alanine & 8.9 & 7.6 \\
Aspartic acid & 16.0 & 12.4 \\
Glutamic acid & 36.8 & 30.1 \\
Glycine & 6.6 & 5.4 \\
Proline & 14.4 & 12.2 \\
Serine & 9.4 & 7.8 \\
\hline
\end{tabular}

\section{Experimental procedures}

\section{Faecal digestibility trial at IVVO}

The apparent faecal digestibility of the dry matter (DM), organic matter (OM), CP, crude fat, crude fibre (CF) and the individual amino acids of the two basal diets $\mathrm{A}$ and $\mathrm{B}$ was determined using four castrated male pigs $(\mathrm{GY} \times(\mathrm{NL} \times \mathrm{FL}))$ per diet. The mean live weight of the pigs was approximately $50 \mathrm{~kg}$. The pigs were individually housed in metabolism cages in an environmentally controlled barn.

The diets were fed as pellets on a restricted basis, twice a day. The amount of feed supplied was approximately 2.7 times the energy requirement for maintenance.

The faeces were collected for 10 days. From chemical composition and digestibility of Weende components, the net energy of the diets was calculated according to the Rostock method (CVB, 1988).

\section{Ileal digestibility trial at $I L O B$}

The apparent ileal digestibility of protein and amino acids of the two basal diets A and $\mathrm{B}$ was determined in four pigs $(\mathrm{GY} \times(\mathrm{NL} \times \mathrm{FL})$ per diet. The pigs were provided with an ileocaecal re-entrant cannula $(20 \mathrm{~mm}$ internal diameter, silicone rubber) according to the technique developed by Easter \& Tanksley (1973). The mean weight of the animals during the experimental period was approximately 45 $\mathrm{kg}$. The pigs were individually housed in metabolism cages in an environmentally 
controlled barn with continuous light. Air temperature varied between 18 and $21{ }^{\circ} \mathrm{C}$. Water was administered with the meal at a ratio of $2: 1$. The amounts of feed given were based on live weight of the animals and energy content of the diets. The feeding level was 2.4 times the energy requirement for maintenance.

The ileal contents were collected quantitatively for 3 times $24 \mathrm{~h}$ on alternate days. During the collection of digesta, the cannula was opened at the center and a polyethylene tube ( $2 \mathrm{~m}$ in length and $8 \mathrm{~cm}$ in diameter) was connected to the proximal part of the cannula. Digesta were collected continuously through the polyethylene tube into a collection container packed in crushed ice. A perforated rubber plug, inserted into the distal part of the cannula, had to prevent the backflow of digesta, and to allow for saline $(0.9 \%)$ infusion into the colon $(2400 \mathrm{ml}$ per $24 \mathrm{~h})$. Digesta were collected hourly, weighed and frozen $\left(-20^{\circ} \mathrm{C}\right)$. After the collection period, a sample of the pooled digesta was freeze -dried, ground and analysed for DM, CP and amino acids.

\section{Growth experiments}

The experimental design (Table 3) was the same for all growth experiments; two ILOB trials and four IVVO trials. The apparent faecal and ileal digestibility of the supplemented L-threonine was assumed to be $100 \%$ (Huisman et al., 1986). The animals $(G Y \times(N L \times F L))$ were group-housed in an artificially heated, ventilated and lighted pig unit. The daily temperature in the pig unit varied between 20 and $23{ }^{\circ} \mathrm{C}$.

After an acclimatization period (17 days for the two ILOB trials, 7 days for the four IVVO trials), the animals were allotted to the five treatments, based on live weight, origin, sex and weight gain after weaning. Per ILOB trial, each experimental diet was fed to four replicate pens of 8 pigs each; two pens with barrows and two with gilts. Per IVVO trial, each diet was fed to 7 group-housed pigs (ratio barrows to gilts was $3: 4$ or $4: 3$ ). The experimental diets were fed as pellets ad libitum for a period of four weeks. Water was also available ad libitum. For all experiments, the mean weight of the animals at the start of the experimental periods was approximately $19 \mathrm{~kg}$.

The animals were weighed individually at the end of the trials (after four weeks

Table 3. Experimental treatments of the growth trials.

\begin{tabular}{|c|c|c|c|c|}
\hline \multirow[t]{2}{*}{ Group } & \multirow[t]{2}{*}{ Diet } & \multicolumn{3}{|c|}{ Content of threonine $\left(\mathrm{g} \mathrm{kg}^{-1}\right)$} \\
\hline & & total & $\begin{array}{l}\text { faecal } \\
\text { digestible }\end{array}$ & $\begin{array}{l}\text { ileal } \\
\text { digestible }\end{array}$ \\
\hline 1 & A & 6.8 & 5.9 & 5.4 \\
\hline 2 & B & 5.6 & 4.7 & 4.2 \\
\hline 3 & $\mathrm{~B}+0.6 \mathrm{~g} \mathrm{~kg}^{-1} \mathrm{~L}$-threonine & 6.2 & 5.3 & 4.8 \\
\hline 4 & $\mathrm{~B}+1.2 \mathrm{~g} \mathrm{~kg}^{-1} \mathrm{~L}$-threonine & 6.8 & 5.9 & 5.4 \\
\hline 5 & $\mathrm{~B}+1.8 \mathrm{~g} \mathrm{~kg}^{-1}$ L-threonine & 7.4 & 6.5 & 6.0 \\
\hline
\end{tabular}


experimental period). At this time, feed intake as well as feed conversion efficiency, calculated as $\mathrm{kg}$ feed $\mathrm{kg}^{-1}$ weight gain, were determined per replicate.

\section{Chemical analysis}

Nitrogen (N) content of the freeze-dried ileal samples was determined according to the Kjeldahl method. CP content was calculated as N 6.25. Amino acids in the basal diets, except methionine, cystine and tryptophan, were determined after acid hydrolysis (6 M HCL during $22 \mathrm{~h}$, at $100^{\circ} \mathrm{C}$ ) according to Slump (1969). Methionine and cystine were determined as methionine sulfon and cysteic acid after oxidation with performic acid according to Moore (1963); the oxidized samples were hydrolysed in the same way as the unoxidized samples. The amino acid composition of the hydrolysates were determined with an automatic amino acid analyzer (Biotronic LC 6001). Tryptophan was determined after hydrolysis with $2.7 \mathrm{~N}$ $\mathrm{Ba}(\mathrm{OH})_{2}\left(8 \mathrm{~h}\right.$ at $\left.130^{\circ} \mathrm{C}\right)$ according to Slump \& Schreuder (1969).

\section{Statistical analysis}

The variables weight gain and feed conversion efficiency were analysed according to a randomized-block design with experiment, sex (only ILOB trials) and treatment as factors. Contrasts were calculated and tested by using least significant difference tests.

To estimate requirement figures, respons curves were fitted according to a quadratic equation, and $95 \%$ confidence intervals were calculated. This was done for the ILOB and the IVVO growth experiments separately, because of the differences in experimental design. For the IVVO experiments, the growth respons curve did not significantly differ from a linear curve, so a confidence interval could not be calculated.

\section{Results and discussion}

Goedhart (1990) reported a small, linear increase in apparent faecal dry matter digestibility for pigs in the weight range of 30 to $100 \mathrm{~kg}$ of $1 \%$ per $20 \mathrm{~kg}$ live weight gain. It is not clear whether the apparent faecal or ileal protein digestibility show the same increase. For the digestibility trials, the weight of the pigs was somewhat higher than for the growth trials $(45-50 \mathrm{~kg}$ versus $20-40 \mathrm{~kg}$ ). The digestibility coefficients determined in this experiment, however, were not only used to calculate the contents of faecal and ileal digestible amino acids for pigs in the weight range of 20 to $40 \mathrm{~kg}$, but also for pigs in the weight range of $45-105 \mathrm{~kg}$ (Lenis \& van Diepen, 1990).

The apparent faecal digestibilites for amino acids, dry matter, organic matter, crude protein, crude fat and crude fibre are shown in Table 4. The apparent differences in faecal digestibilities of individual amino acids were small. In both basal diets the faecal (Table 4) and ileal (Table 5) digestibility of cystine and threonine was found to be somewhat lower than that of other amino acids. 
Table 4. Faecal digestibility coefficients $(\%)$ of individual amino acids, dry matter, organic matter, crude protein, crude fat and crude fibre $( \pm S D)$.

\begin{tabular}{lcc}
\hline & Basal A & Basal B \\
Isoleucine & & \\
Leucine & $89.1 \pm 0.9$ & $88.1 \pm 1.3$ \\
Lysine & $91.1 \pm 0.6$ & $90.6 \pm 1.1$ \\
Methionine & $88.9 \pm 0.6$ & $89.5 \pm 1.2$ \\
Cystine & $89.4 \pm 1.2$ & $90.2 \pm 1.1$ \\
Phenylalanine & $86.7 \pm 1.0$ & $84.6 \pm 1.0$ \\
Threonine & $90.5 \pm 0.7$ & $88.5 \pm 1.0$ \\
Tryptophan & $86.3 \pm 1.1$ & $83.3 \pm 1.8$ \\
Valine & & $88.1 \pm 1.0$ \\
Arginine & $88.3 \pm 0.8$ & $86.3 \pm 1.4$ \\
Histidine & $92.1 \pm 0.5$ & $90.4 \pm 1.0$ \\
& $90.3 \pm 0.7$ & $90.0 \pm 1.0$ \\
Dry matter & & \\
Organic matter & $88.0 \pm 0.4$ & $97.9 \pm 0.1$ \\
Crude protein & $90.4 \pm 0.5$ & $85.9 \pm 0.1$ \\
Crude fat & $88.7 \pm 0.8$ & $81.5 \pm 1.0$ \\
Crude fibre & $72.7 \pm 1.2$ & $42.1 \pm 3.9$ \\
\hline
\end{tabular}

Table 5. Ileal digestibility $(\%)$ of amino acids, dry matter and crude protein ( \pm SD).

\begin{tabular}{lcc}
\hline & Basal A & Basal B \\
Isoleucine & $86.8 \pm 0.8$ & $86.4 \pm 0.8$ \\
Leucine & $91.2 \pm 2.6$ & $88.6 \pm 0.7$ \\
Lysine & $87.0 \pm 1.9$ & $87.7 \pm 0.6$ \\
Methionine & $90.8 \pm 0.5$ & $91.5 \pm 0.6$ \\
Cystine & $76.0 \pm 1.9$ & $73.8 \pm 1.8$ \\
Phenylalanine & $89.1 \pm 2.7$ & $83.0 \pm 1.1$ \\
Tyrosine & $81.2 \pm 1.9$ & $79.6 \pm 1.2$ \\
Threonine & $80.0 \pm 1.7$ & $75.7 \pm 1.4$ \\
Tryptophan & $78.9 \pm 0.7$ & $80.8 \pm 1.6$ \\
Valine & $84.6 \pm 0.8$ & $82.7 \pm 1.0$ \\
Arginine & $89.9 \pm 0.8$ & $86.9 \pm 0.6$ \\
Histidine & $84.3 \pm 1.0$ & $84.6 \pm 0.9$ \\
& & \\
Alanine & $84.1 \pm 0.7$ & $82.3 \pm 0.7$ \\
Aspartic acid & $83.8 \pm 1.0$ & $79.7 \pm 1.0$ \\
Glutamic acid & $90.4 \pm 0.1$ & $88.4 \pm 0.4$ \\
Glycine & $77.0 \pm 1.3$ & $70.7 \pm 1.9$ \\
Proline & $87.8 \pm 1.2$ & $86.7 \pm 1.1$ \\
Serine & $83.2 \pm 1.4$ & $81.1 \pm 0.9$ \\
Dry matter & & $76.6 \pm 0.8$ \\
Crude protein & $77.9 \pm 1.5$ & $80.4 \pm 0.9$ \\
\hline
\end{tabular}


Compared to the faecal digestibilities, for all indispensable amino acids, except for methionine, lower ileal values were found. The amino acids threonine, cystine and tryptophan disappeared to the largest extent in the large intestine. These findings are in agreement with those reported by Sauer \& Ozimek (1986) and van Leeuwen et al. (1987). The net synthesis of methionine in the large intestine observed in our study agrees with the finding of van Weerden et al. (1980), which may partly be attributed to the conversion of cystine to methionine in the large intestine.

The results of the growth trials performed at ILOB are summarized in Table 6. In both trials no significant $(P>0.05)$ treatment $\times$ sex interaction was found, so the results for both sexes are combined. Weight gain of the pigs was quite good, being on average $675 \mathrm{~g} \mathrm{~d}^{-1}$ during the experimental periods of 4 weeks. The results show that weight gain was improved significantly upto a dietary threonine level of $6.8 \mathrm{~g} \mathrm{~kg}^{-1}$. Above this level, weight gain was not clearly affected. Maximum efficiency of feed utilization was achieved at the highest dietary level of threonine of $7.4 \mathrm{~g} \mathrm{~kg}^{-1}$. However, the improvement in feed conversion efficiency above a

Table 6. Mean combined results of the two ILOB growth experiments for weight gain $\left(\mathrm{g} \mathrm{kg}^{-1}\right)$, feed conversion efficiency ( $\mathrm{kg}$ feed $\mathrm{kg}^{-1}$ gain) and daily feed intake $\left(\mathrm{kg} \mathrm{d}^{-1}\right.$ animal-1).

\begin{tabular}{|c|c|c|c|c|c|c|}
\hline \multirow[t]{2}{*}{ Group } & \multirow[t]{2}{*}{ Diet } & \multicolumn{2}{|c|}{ Threonine content $\left(\mathrm{g} \mathrm{kg}^{-1}\right)$} & \multirow{2}{*}{$\begin{array}{l}\text { Weight } \\
\text { gain }{ }^{1}\end{array}$} & \multirow{2}{*}{$\begin{array}{l}\text { Feed/ } \\
\text { gain' }\end{array}$} & \multirow{2}{*}{$\begin{array}{l}\text { Feed } \\
\text { intake }\end{array}$} \\
\hline & & total & $\begin{array}{l}\text { ileal } \\
\text { digestible }\end{array}$ & & & \\
\hline 1 & A & 6.8 & 5.4 & $707 \mathrm{ab}$ & $1.91^{\mathrm{a}}$ & 1.36 \\
\hline 2 & B & 5.6 & 4.2 & $550^{\circ}$ & $2.27 \mathrm{c}$ & 1.25 \\
\hline 3 & B & 6.2 & 4.8 & $671^{b}$ & $2.05^{b}$ & 1.37 \\
\hline 4 & B & 6.8 & 5.4 & $725 a$ & $1.91^{\mathrm{a}}$ & 1.38 \\
\hline 5 & B & 7.4 & 6.0 & $729 a$ & $1.89 \mathrm{a}$ & 1.37 \\
\hline
\end{tabular}

1 Values within this column not having one letter in common differ significantly $(P<0.05)$.

Table 7. Mean combined results of the four IVVO growth experiments for weight gain $\left(\mathrm{g} \mathrm{kg}^{-1)}\right.$, feed conversion efficiency ( $\mathrm{kg}$ feed $\mathrm{kg}^{-1}$ gain) and daily feed intake $\left(\mathrm{kg} \mathrm{d}^{-1}\right.$ animal-1).

\begin{tabular}{|c|c|c|c|c|c|c|}
\hline \multirow[t]{2}{*}{ Group } & \multirow[t]{2}{*}{ Diet } & \multicolumn{2}{|c|}{ Threonine content $\left(\mathrm{g} \mathrm{kg}^{-1}\right)$} & \multirow{2}{*}{$\begin{array}{l}\text { Weight } \\
\text { gain }{ }^{1}\end{array}$} & \multirow{2}{*}{$\begin{array}{l}\text { Feed/ } \\
\text { gain' }\end{array}$} & \multirow{2}{*}{$\begin{array}{l}\text { Feed } \\
\text { intak }\end{array}$} \\
\hline & & total & $\begin{array}{l}\text { ileal } \\
\text { digestible }\end{array}$ & & & \\
\hline 1 & A & 6.8 & 5.4 & $696^{\mathrm{a}}$ & $1.91^{\mathrm{a}}$ & 1.33 \\
\hline 2 & B & 5.6 & 4.2 & $604^{b}$ & $2.20^{\mathrm{b}}$ & 1.33 \\
\hline 3 & B & 6.2 & 4.8 & $650^{\mathrm{ab}}$ & $2.01^{\mathrm{b}}$ & 1.31 \\
\hline 4 & B & 6.8 & 5.4 & $693^{a}$ & $1.95^{\mathrm{a}}$ & 1.35 \\
\hline 5 & B & 7.4 & 6.0 & $689 a$ & $1.91^{\mathrm{a}}$ & 1.31 \\
\hline
\end{tabular}

1 Values within this column not having one letter in common differ significantly $(P<0.05)$. 
dietary level of $6.8 \mathrm{~g} \mathrm{~kg}^{-1}$ was not significant. Daily feed intake was not affected above a dietary threonine level of $6.2 \mathrm{~g} \mathrm{~kg}^{-1}$.

The results of the IVVO trials (Table 7) agree well with those of the ILOB trials. The mean daily weight gain, being $665 \mathrm{~g}$ per animal was almost similar to that obtained in the ILOB trials. Maximum weight gain was again obtained at a dietary threonine level of $6.8 \mathrm{~g} \mathrm{~kg}^{-1}$.

In the IVVO trials also maximum efficiency of feed utilization was found at the highest $\left(7.4 \mathrm{~g} \mathrm{~kg}^{-1}\right)$ dietary level of threonine. However, similar to the ILOB trials, the improvement in feed conversion efficiency above a dietary threonine level of 6.8 $\mathrm{g} \mathrm{kg}^{-1}$ was not significant. Daily feed intake was not affected clearly in the IVVO trials by increasing the dietary threonine level from 5.6 to $7.4 \mathrm{~g} \mathrm{~kg}^{-1}$.

In Figure 1 the respons curve of weight gain to increasing ileal digestible threonine level is given, and Figure 2 shows the respons curve of feed conversion efficiency to an increase in ileal digestible threonine level. From the regression curves it was estimated that for obtaining maximum weight gain, the dietary content of ileal digestible threonine should be approximately $5.7 \mathrm{~g} \mathrm{~kg}^{-1}$ (ILOB: $5.7 \mathrm{~g} \mathrm{~kg}^{-1}, 95 \%$ confidence interval 5.45-6.55 $\mathrm{g} \mathrm{kg}^{-1}$, IVVO: $5.8 \mathrm{~g} \mathrm{~kg}^{-1}$ ). This figure corresponds with $7.1 \mathrm{~g} \mathrm{~kg}^{-1}$ total dietary threonine and $6.2 \mathrm{~g} \mathrm{~kg}^{-1}$ faecal digestible threonine.

Maximum efficiency of feed utilization was calculated to be found at an ileal digestible threonine content of $6.0 \mathrm{~g} \mathrm{~kg}^{-1}$ (ILOB: $6.1 \mathrm{~g} \mathrm{~kg}^{-1}, 95 \%$ confidence interval 5.74-7.24, IVVO: $5.9 \mathrm{~g} \mathrm{~kg}^{-1}, 95 \%$ confidence interval 5.57-7.17). This corresponds with $7.4 \mathrm{~g} \mathrm{~kg}^{-1}$ total dietary threonine and $6.5 \mathrm{~g} \mathrm{~kg}^{-1}$ faecal digestible threonine.

These results indicate, that for obtaining maximum efficiency of feed utilization, threonine requirement is somewhat higher than for obtaining maximum weight gain. This is in agreement with the results of Grosbach et al. (1985) and of Rosell \& Zimmerman (1985).

In literature the requirement for threonine and other essential amino acids is often expressed as a percentage of the dietary level of lysine. The requirement values of $7.1 \mathrm{~g} \mathrm{~kg}^{-1}$ threonine for maximum weight gain, and $7.4 \mathrm{~g} \mathrm{~kg}^{-1}$ threonine for maximum efficiency of feed utilization, found in our studies, correspond with $68 \%$ and $71 \%$ of the dietary level of lysine, respectively. These values are close to the value recommended by Wang \& Fuller (1989) of $72 \%$. However, ileal digestibility is a better estimate than faecal digestibility for amino acid valuation. Based on the ileal digestibility values found in our studies, the requirement figures for ileal digestible threonine of $5.7 \mathrm{~g} \mathrm{~kg}^{-1}$ and $6.0 \mathrm{~g} \mathrm{~kg}^{-1}$, correspond with approximately $63 \%$ and $66 \%$ of the dietary level of ileal digestible lysine, being $9.1 \mathrm{~g} \mathrm{~kg}^{-1}$.

At equal threonine levels almost the same performance was achieved on both basal diets (Table 6 and 7). This means that the dietary level of protein in a pig diet can be reduced from 185 to $160 \mathrm{~g} \mathrm{~kg}^{-1}$, when the first limiting amino acids are added to the low protein diet. As a result this will contribute substantially to the reduction of the $\mathrm{N}$ excretion. The practical potentials, however, depend on the price relations between protein bound amino acids in feed components and synthetic amino acids. 


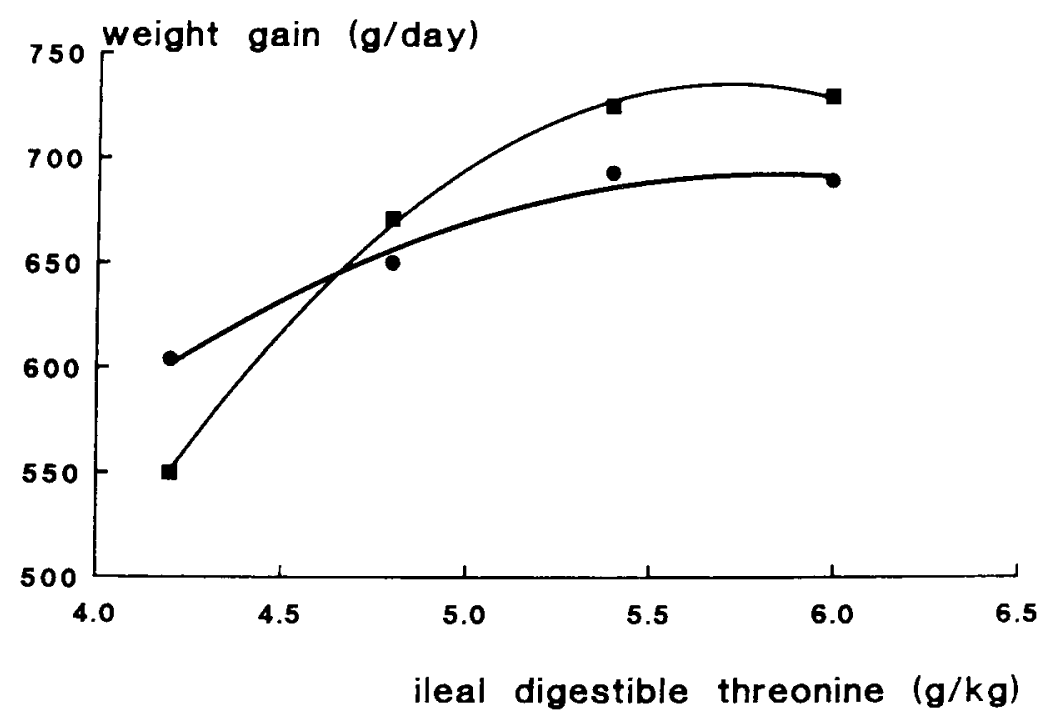

Fig. 1. Weight gain $\left(\mathrm{g} \mathrm{d}^{-1}\right)$ as related to ileal digestible threonine content in the diet $\left(\mathrm{g} \mathrm{kg}^{-1}\right)$. Regression curves based on the results of the ILOB $\left(\boldsymbol{U} ; \mathrm{Y}=-1870.04+912.87 \mathrm{X}-79.99 \mathrm{X}^{2}\right)$ and the IVVO $\left(\bullet ; \mathrm{Y}=-572.56+439.23 \mathrm{X}-38.13 \mathrm{X}^{2}\right)$ growth experiments.

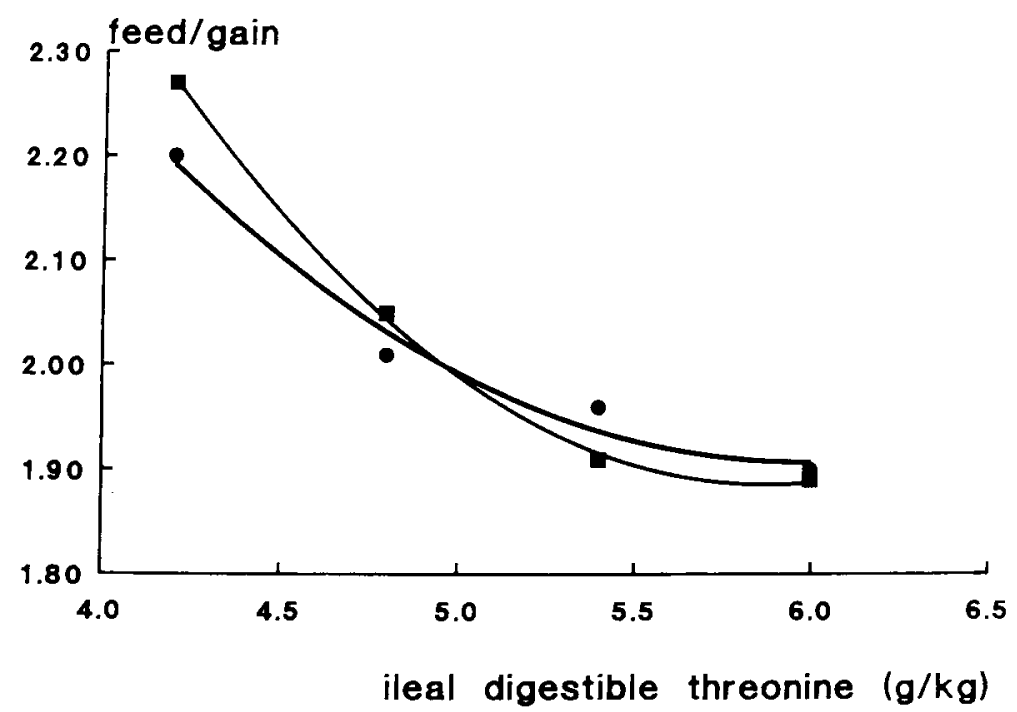

Fig. 2. Feed conversion efficiency (feed/gain) as related to ileal digestible threonine content in the diet $\left(\mathrm{g} \mathrm{kg}^{-1}\right)$. Regression curves based on the results of the ILOB $\left(\square ; \mathrm{Y}=6.12-1.398 \mathrm{X}+0.115 \mathrm{X}^{2}\right)$ and the IVVO $\left(\bullet ; \mathrm{Y}=5.45-1.16 \mathrm{X}+0.99 \mathrm{X}^{2}\right)$ growth experiments. 


\section{References}

ARC, 1981. Agricultural Research Council. The nutrient requirements of pigs. Commonwealth Agriculture Bureaux, Slough, $307 \mathrm{pp}$.

CVB, 1988. Table on feedstuffs. Information about composition, digestibility and feeding value. (In Dutch.) Centraal Veevoeder Bureau in Nederland, Lelystad.

Easter, R. A. \& T. D. Tanksley Jr., 1973. A technique for re-entrant ileocecal cannulation of swine. Journal of Animal Science 36:1099-1103.

Goedhart, P. W., 1990. Experimental design for comparative digestibility trials with pigs: limitations of latin squares. Animal Production 50:373-378.

Gomez-Rojas, V. M., G. L. Cromwell \& T. S. Stahly, 1985. Threonine requirement of the growing pig from 16 to $33 \mathrm{~kg}$ body weight. Journal of Animal Science 61 (Suppl. 1):280.

Grosbach, D. A., A. J. Lewis \& E. R. Peo Jr., 1985. An evaluation of threonine and isoleucine as the third and fourth limiting amino acids in corn for growing swine. Journal of Animal Science $60: 487-494$.

Günther, K. D., 1989. Untersuchungen zur Threonin Versorgung in der Ferkelfütterung. Züchtungskunde 61:311-316.

Hermann, U., 1988. Report on the workshop 1: New methods for the investigation of protein digestibility and absorption of amino acids in non-ruminants. Wissenschaftliche Zeitschrift der Wilhelm-Pieck Universität Rostock, Naturwissenschaftliche Reihe 37:85-87.

Huisman, J., P. H. U. de Vries, E. J. van Weerden \& H. L. Bertram, 1986. The availability of synthetic methionine in pigs. Journal of Animal Physiology and Animal Nutrition 55:267-272.

Leeuwen, P. van, W. C. Sauer, J. Huisman, E. J. van Weerden, D. van Kleef \& L. A. den Hartog, 1987. Methodological aspects for the determination of amino acid digestibilities in pigs fitted with ileocecal re-entrant cannulas. Journal of Animal Physiology and Animal Nutrition 58:122-133.

Lenis, N. P., 1989. Lower nitrogen excretion in pig husbandry by feeding: current and future possibilities. Netherlands Journal of Agricultural Science 37:61-70.

Lenis, N. P. \& J. Th. M. van Diepen, 1990. Amino acid requirements of pigs. 3. Requirement for apparent digestible threonine of pigs in different stages of growth. Netherlands Journal of Agricultural Science 38: 609-622.

Lewis, A. J. \& E. R. Peo Jr., 1986. Threonine requirement of pigs weighing 5 to $15 \mathrm{~kg}$. Journal of Animal Science 62:1617-1623.

Moore, S., 1963. On the determination of cystine as cysteic acid. Journal of Biological Chemistry 238:235-237.

Rosell, V. L. \& D. R. Zimmerman, 1985. Threonine requirement of pigs weighing 5 to $15 \mathrm{~kg}$ and the effect of excess methionine in diets marginal in threonine. Journal of Animal Science 60:480-486.

Sauer, W. C. \& L. Ozimek, 1986. Digestibility of amino acids in swine: results and their practical applications. A review. Livestock Production Science 15:367-388.

Slump, P., 1969. Characterization of the nutritive value of food proteins by amino acid composition and the effect of heat and alkali treatment on the availability of amino acids (in Dutch, English summary). Doctoral Thesis, Free University Amsterdam, $131 \mathrm{pp}$.

Slump, P. \& H. A. W. Schreuder, 1969. Determinations of tryptophan in foods. Analytical Biochemistry 27:182-186.

Wang, T. C. \& M. F. Fuller, 1989. The optimum dietary amino acid pattern for growing pigs 1. Experiments by amino acid deletion. British Journal of Nutrition 62:77-89.

Weerden, E. J. van, P. Slump \& J. Huisman, 1980. Amino acid digestion in different parts of the intestinal tract of pigs. Proceedings of the 3rd EAAP Symposium on Protein Metabolism and Nutrition, Braunschweig. European Association for Animal Production 27:207-214. 